\title{
Surgery for urological cancers
}

Urological cancers, particularly prostate and bladder cancer, represent some of the most commonly diagnosed malignancies. As such, globally they account for a large burden of suffering, health-care resources and deaths. Like many other malignancies, the care of urological cancers has increasingly become multi-disciplinary, with surgery, radiation and systemic therapies each playing an important role supplemented significantly by nursing and allied health interventions.

Nonetheless, surgical procedures retain a central role in managing these cancers, whether it be for diagnosis as in prostate biopsy or bladder tumour resection, definitive curative treatment by tumour excision, staging by pelvic or inguinal lymphadenectomy, or salvage therapy as in retroperitoneal lymph node dissection. The range of surgical approaches to urological cancers have evolved significantly over time and continue to do so—driven by technological developments and crucial imperatives of organ-sparing and minimally invasive approaches where feasible.

This special series of reviews on the important surgical procedures for urological cancers, each aiming to describe the surgical principles and summarise the literature on outcomes and complications. For newer and developing procedures such as robotic partial nephrectomy and penile-sparing surgery, these reviews should enable additional uptake and dissemination. Conversely, for well-established procedures such as bladder tumour resection and pelvic lymphadenectomy, they will serve the purpose of reinforcing good surgical technique and appropriate patient selection. I hope the end result will be further improvement in the surgical management of urological cancers.

I sincerely thank the Journal for the opportunity to edit this special series, and all the authors for the very significant contributions they have made.

\section{Acknowledgments}

Funding: None.

\section{Footnote}

Provenance and Peer Review: This article was commissioned by the editorial office, Translational Andrology and Urology for the series "Surgery for Urologic Cancers". The article did not undergo external peer review.

Conflicts of Interest: The author has completed the ICMJE uniform disclosure form (available at http://dx.doi.org/10.21037/ tau-2019-suc-20). The series "Surgery for Urologic Cancers" was commissioned by the editorial office without any funding or sponsorship. SS served as the unpaid Guest Editor of the series and serves as an unpaid editorial board member of Translational Andrology and Urology from Jul 2018 to Jun 2020. The author has no other conflicts of interest to declare.

Ethical Statement: The author is accountable for all aspects of the work in ensuring that questions related to the accuracy or integrity of any part of the work are appropriately investigated and resolved.

Open Access Statement: This is an Open Access article distributed in accordance with the Creative Commons AttributionNonCommercial-NoDerivs 4.0 International License (CC BY-NC-ND 4.0), which permits the non-commercial replication and distribution of the article with the strict proviso that no changes or edits are made and the original work is properly cited (including links to both the formal publication through the relevant DOI and the license). See: https://creativecommons.org/ licenses/by-nc-nd/4.0/. 


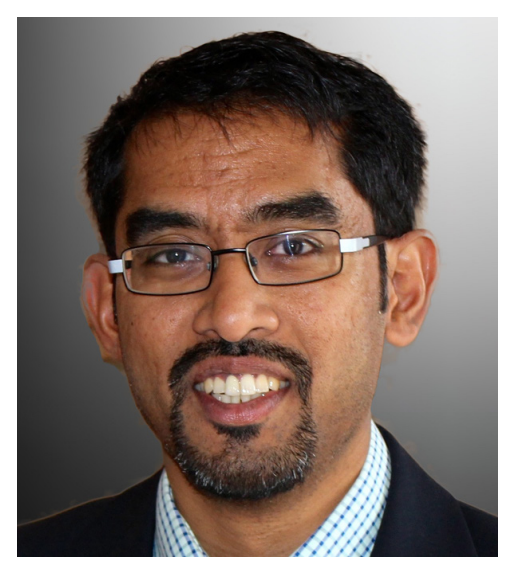

Shomik Sengupta

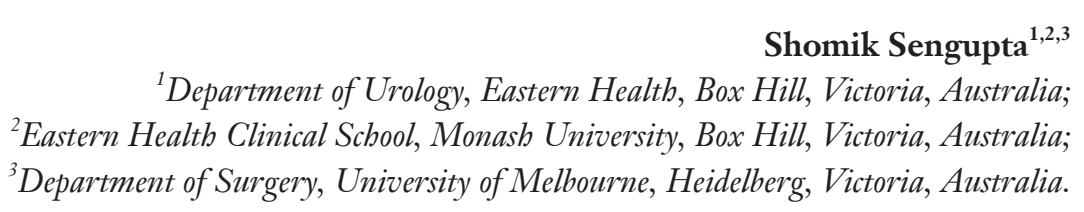

(Email: shomik.sengupta@monash.edu)

Submitted Jul 23, 2020. Accepted for publication Aug 21, 2020. doi: $10.21037 /$ tau-2019-suc-20

View this article at: http://dx.doi.org/10.21037/tau-2019-suc-20

Cite this article as: Sengupta S. Surgery for urological cancers. Transl Androl Urol 2020;9(6):3007-3008. doi: 10.21037/tau-2019suc-20 